\title{
STRENGTH, MICRO-STRUCTURE \& DURABILITY INVESTIGATIONS OF LATERITIC CONCRETE WITH PALM KERNEL SHELL (PKS) AS PARTIAL REPLACEMENT OF COARSE AGGREGATES
}

\author{
Christopher Fapohunda $^{1 *}$ - Hussein Bello ${ }^{1}$ - Taiwo Salako ${ }^{1}$ - Suaib Tijani ${ }^{1}$ \\ ${ }^{1}$ Department of Civil Engineering, Faculty of Engineering, Federal University, Oye-Ekiti, Ekiti State, Nigeria
}

\begin{tabular}{l} 
ARTICLE INFO \\
\hline Article history: \\
Received: 26. 3. 2018. \\
Received in revised form: 18. 6. 2018. \\
Accepted: 19.6 .2018$. \\
\hline Keywords: \\
Compressive strength \\
Density \\
Lateritic concrete \\
Microstructure \\
Palm kernel shell \\
Workability \\
\hline DOI: http://doi.org/10.30765/er.40.2.07
\end{tabular}

\section{Introduction}

Concrete is assumed to be a predominant construction material in the world for many reasons.

\begin{abstract}
This paper presents the results of investigation conducted to evaluate structural performance of lateritic concrete containing palm kernel shell (PKS) as partial replacement of coarse aggregate by weight. The properties evaluated were: workability, density, compressive strength, microstructure, sorptivity, and water absorption of lateritic concrete with PKS specimens. The coarse aggregate fraction of the lateritic concrete was partially replaced with PKS of up to $50 \%$ at interval of $10 \%$ by weight. The results showed that: (i) the use of PKS to partially replace the coarse aggregate in lateritic concrete resulted in harsh concrete with low workabilities, (ii) lateritic concrete with PKS as partial replacement of coarse aggregate of up to $50 \%$ developed densities that can be used for normal concrete application, (iii) lateritic concrete with PKS as partial replacement of coarse aggregate of up to $10 \%$ developed strength that is comparable to the specimens without PKS, (iv) the SEM images of lateritic concrete samples showed a progressively porous internal structure with PKS and (v) lateritic concrete with PKS as partial replacement of coarse aggregate results in porous material but became less porous at longer curing ages. It can be concluded from these results that the replacement of the coarse aggregate constituent with PKS by weight not exceeding $10 \%$, in the production of lateritic concrete, resulted in a material with satisfactory structural performance.
\end{abstract}

One of them is the ease with which it can be produced in a variety of strengths, stiffnesses, unit weights, porosities and durability characteristics and properties, by using the same four basic components of cement, fine aggregates, coarse aggregates and

\footnotetext{
${ }^{*}$ Corresponding Author: Tel.: +2348066020802

E-mail address: christopher.fapohunda@fuoye.edu.ng
} 
water. Also concrete allows any of these four basic components of its composition to be altered, modified, or partially replaced by another compatible material to produce entirely new concrete. One of such concrete is lateritic concrete. Lateritic concrete is a concrete in which fine aggregates fractions of the mix component have been partially replaced by laterite. Fine aggregates in the form of river sand and sand deposits are becoming scarce and expensive. This is due to the fact that sand deposits are being exhausted and expensive equipment are required in the dredging of river sand. In addition, sand is often hauled over a long distance to the construction site. The usage of sand in the production of structural concrete means consumption of non-renewable resources. This is a serious sustainability issue which engineers are now poised to address in order to prevent endangering of the future generations to cater for themselves. On the other hand, laterite is cheap, assessable, environmentally friendly and abundantly available material, especially in the tropical region; and potentially in all other parts of earth where laterization is expected to take place [1]. Laterite has been used extensively as construction material for construction of walls, shelters from time immemorial; and approximately $30 \%$ of the world population still lives in laterite-based structures $[2,3]$. Many researchers have investigated the possibility of using laterite as partial replacement of sand in the production of structural concrete. Their results agreed that structural concrete of comparable compressive strength in relation to control can be obtained by replacing the fine aggregates of the mix with laterite ones up to $30-40 \%$ by weight [ $4-8$ ]. Further, there is ever-increasing demand for concrete for the construction of developmental projects, both in the developed and developing nations. Continual consumption of materials such as gravel and granite, without the means of renewability, portends a danger to future generations. This has motivated researchers in recent times to beam their search light to potential sustainable materials suitable to be used as partial replacement for coarse aggregates. In recent times, palm kernel shells have been found useful for the production of structural lightweight concrete $[9,10]$. Palm kernel shells (PKS) are an agricultural organic waste material produced in abundance from crude palm oil producing factories in Asia and Africa. The present work investigates the effect of partially replacing the coarse aggregates fractions of lateritic concrete with palm kernel shell (PKS). The lateritic concrete used in this investigation had 30\% laterite as partial replacement of sand, while the coarse aggregate components was partially replaced with PKS at intervals from $10 \%$ to $50 \%$. The parameters investigated: workability, density, compressive strength and microstructure of the concrete, sorptivity and water absorption, using appropriate specimens.

\section{Materials and methods}

\subsection{Materials and mix proportions}

The materials used for this investigation are: ordinary Portland cement (OPC), fine aggregate, coarse aggregate, palm kernel shell (PKS), laterite and portable water. The cement was an ordinary Portland cement meeting the requirements of [11, 12] and classified as grade 42.5. The fine aggregate, was river sand, which was obtained from OkoOotunja, a sand deposit location, closed to IkoleEkiti, a town in Nigeria. The sand was dried and sieved through a $2.36 \mathrm{~mm}$ sieve and treated in accordance with [13]. For the coarse aggregates, granite chipping obtained from quarry, with sizes ranges from $4.75 \mathrm{~mm}$ to $20 \mathrm{~mm}$ was used. The quarry was located in Ikole Ekiti town, where the Faculty of Engineering Campus of the Federal University Oye-Ekiti, Nigeria was located. The palm kernel shells (PKS) were obtained from palm oil mills in Ikole Ekiti town. For the Laterite, an area in Ikole Ekiti, confirmed to be lateritic in composition, according to the works of [14] served as the source. The water used for the experiment was potable tap water, free from any dissolved metal or ions that might inhibit the setting and hydration process of the concrete. The mix design is given in Table 1 . The mix ratio adopted was $1: 2: 4$ with water-cement ratio of 0.5 , which were representative of the practice in Nigeria.

Table 1. The mix proportion $\left(\mathrm{kg} / \mathrm{m}^{3}\right)$

\begin{tabular}{|c|c|c|c|c|c|c|c|}
\hline \multirow{2}{*}{\multicolumn{2}{|c|}{$\begin{array}{l}\text { Mix } \\
\text { Designation }\end{array}$}} & \multirow{3}{*}{\begin{tabular}{|r|} 
CEM \\
341 \\
\end{tabular}} & \multicolumn{2}{|l|}{ FA } & \multicolumn{2}{|l|}{ CA } & \multirow[t]{2}{*}{ W } \\
\hline & & & \multicolumn{2}{|r|}{ LAT } & \multicolumn{2}{|r|}{ PKS } & \\
\hline Мс & Normal & & 682 & 0.00 & 1365 & 0.00 & 171 \\
\hline $\mathrm{M}_{0}$ & $0 \% \mathrm{PKS}$ & 341 & 478 & 205 & 1365 & 0.00 & 171 \\
\hline $\mathrm{M}_{10}$ & $10 \%$ PKS & 341 & 478 & 205 & 1228 & 137 & 171 \\
\hline $\mathrm{M}_{20}$ & $20 \%$ PKS & 341 & 478 & 205 & 1092 & 273 & 171 \\
\hline $\mathrm{M}_{30}$ & $30 \%$ PKS & 341 & 478 & 205 & 955 & 409 & 171 \\
\hline $\mathrm{M}_{40}$ & $40 \% \mathrm{PKS}$ & 341 & 478 & 205 & 819 & 546 & 171 \\
\hline $\mathrm{M}_{50}$ & $50 \%$ PKS & 341 & 478 & 205 & 682 & 682 & 170 \\
\hline
\end{tabular}


The laterite content of the mix was kept constant at $30 \%$, but the coarse aggregate was replaced with palm kernel shell (PKS) at the interval from $10 \%$ to $50 \%$. The concrete ingredients were batched by weight, mixed, and place in cubes, and then compacted. The cubes were demoulded after 24 hrs., and then moist-cured in a curing bath until the day of testing (at $7,14,21,28,60$, and 90 days). A total number of $126150 \times 150 \times 150 \mathrm{~mm}$ and 36 numbers of $100 \times 100 \times 100 \mathrm{~mm}$ cube specimens were produced and tested.

\subsection{Experimental investigations}

\subsubsection{Preliminary investigations}

In order to characterize the properties of the aggregates used, some preliminary investigations were carried out on the fine aggregates, coarse aggregates, laterite and palm kernel shell (PKS). Some of the tests that were carried out included: density, specific gravity, porosity, water absorption, crushing test, aggregate impact test, abrasion test, and mechanical analysis. All these were carried out in accordance to the relevant standards.

\subsubsection{Main investigations Workability test}

In order to assess the workability of lateritic concrete with PKS as partial replacement of coarse aggregate, slump test was conducted. The test was done in accordance to the provisions of [15] for each replacement of coarse aggregate by PKS before the concrete was cast into moulds.

\section{Density and compressive strength tests}

Determination of the density and compressive strength of the lateritic specimens with PKS as partial replacement of coarse aggregates were through $150 \mathrm{~mm} \times 150 \mathrm{~mm} \times 150 \mathrm{~mm}$ cube molds. While the density determination was conducted in accordance to [16], the compressive test was done with respect to the provisions of [17]. The cubes were tested for their density and compressive strength at $7,14,21,28,60$ - and 90-days curing ages respectively. The strength characteristics of each cube were determined on $2000 \mathrm{kN}$ WAW2000B computerized electrohydraulic servo universal testing machine, with accuracy of $\pm 1 \%$ of test force. At each testing age, three specimens tested the values of the crushing load and were averaged and used to evaluate the mean strength. Prior to testing on the testing day, the cubes were weighed and the values recorded were used to compute the density of the specimens.

\section{Microstructural investigations}

Scanning electron microscopy equipment was used to examine the morphological structures of the lateritic concrete specimens with PKS, which involves the characterization of the cement paste and the paste/aggregate interface. The equipment model ASPEX 3020 scanning electron microscopy (SEM), comes with energy dispersive spectrometer (EDS), allows high resolution identification of elements and compounds present in prepared 2-D cross-sections of aggregate samples to be obtained.

\section{Water absorption test}

According to [18, 19] a coefficient of water absorption is suggested as a measure of permeability of water. For this test, $100 \mathrm{~mm} \times 100 \mathrm{~mm} \times 100 \mathrm{~mm}$ concrete cubes (after casting) were immersed in water for 28 and 90 days for curing. The cube specimens were taken out of the curing bath, and preconditioned by drying in an oven at $105^{\circ} \mathrm{C}$ until a constant weight was reached. In this investigation, the constant weight was reached at 5 days rather than 10 days as in the work of [18], due to its porosity. The specimens were then allowed to cool in a sealed container for three days. The sides of the concrete samples were coated with silicone sealant in order to allow the flow in one direction. Then the samples in a vertical position were kept partially immersed to a depth of $5 \mathrm{~mm}$ at one end while the rest of the portions were kept exposed to the laboratory air as shown in Fig 1 adapted from [18].

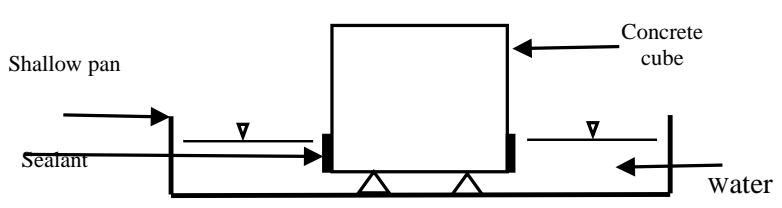

Figure 1. Set up for the measurement of a coefficient of water absorption and sorptivity of the concrete specimens (adaptation from [18])

The quantity of water absorbed during the first 60 min was calculated. The coefficient of water absorption values of RHA blended concrete specimens after 28 and 90 days of moisture curing was determined using the formula used by [18]:

$$
K_{a}=\left[\frac{Q}{A}\right]^{2} \times \frac{1}{t}
$$

Where $K_{a}$ is the coefficient of water absorption $\left(\mathrm{m}^{2} / \mathrm{s}\right), Q$ is the quantity of water absorbed $\left(\mathrm{m}^{3}\right)$ by 
the oven dry specimen in time $(\mathrm{t}), t$ is $3600 \mathrm{~s}$ and $A$ is the surface area $\left(\mathrm{m}^{2}\right)$ of concrete specimen through which water penetrates.

\section{Sorptivity test}

Sorptivity is a measure of the capillary forces exerted by the pore structure causing fluids to be drawn into the body of the material [18, 20]. Sorptivity test was performed in accordance with [21]. This test involves casting $100 \mathrm{~mm} \times 100 \mathrm{~mm} \times$ $100 \mathrm{~mm}$ concrete cube specimens, which were moist-cured for 28 and 90 days for curing. The specimens were then taken out of the curing bath, and heated in an oven at $105^{\circ} \mathrm{C}$ until a constant weight was attained at about 5 days. The specimens were then allowed to gradually cool at the room temperature for 24 hrs. The sides of the cubes were coated with silicone sealant to allow the flow of water on only one surface of the cube specimen. The cube specimens were immersed in water in a shallow pan to a depth of $5 \mathrm{~mm}$ on one surface. The initial mass of the cube was taken; subsequent mass measurements were taken at $4,8,10,20,30,60,90$ and $120 \mathrm{~min}$. The sorptivity of the specimens was calculated by using the formula suggested by [22].

$$
i=\frac{s}{\sqrt{t}}
$$

Where $i=$ the cumulative water absorption per unit area of the surface $\left(\mathrm{m}^{3} / \mathrm{m}^{2}\right) ; S$ is the sorptivity $\left(\mathrm{mm} / \mathrm{min}^{0.5}\right)$ and $t$ is the elapsed time (s). The sorptivity of the specimens was determined after 28 and 90 days of water curing. The setup for the measurement of sorptivity values of the concrete cubes is shown in Fig. 1 (adaptation from [18]).

\section{Results and discussions}

\subsection{Preliminary investigations}

The results of the preliminary investigations are presented in Table 2 and Fig. 2.

From Table 2, it can be observed that the values obtained for weight-based parameters like: bulk density and the specific gravity, for coarse and fine aggregates were higher than the values obtained for PKS and laterite. These results were in agreement with values obtained by [6, 23]. Also, the values for porosity and water absorption obtained for PKS are higher than that of coarse aggregate. This suggests that PKS is more porous than the coarse aggregate. Furthermore, the values of aggregate crushing value
(ACV), aggregate abrasion value (AAV) and aggregate impact value (AIV) obtained for PKS are lower than that of coarse aggregate. The lower ACV for PKS means a better resistance to compressive load and surface abrasion than the coarse aggregate [24]. The ACV values for both the PKS and the coarse aggregate are with the maximum stipulated of $30 \%$ by [25] for concrete production. The lower AAV of PKS means higher resistance to abrasion than coarse aggregate. However, the values of 0.85 and 1.97 for both coarse aggregate and PKS are lower than maximum recommended by [26] of between 30 and $50 \%$. Also, the AIV for both the coarse aggregate and PKS are lower than 25\% $45 \%$ allowed by [27]. The plot from the particle size analysis is shown in Fig. 2.

Table 2. Some physical properties of the aggregates, laterites and PKS used

\begin{tabular}{|l|c|c|c|c|}
\hline Property & CA & PKS & FA & LAT \\
\hline Bulk Density $\left(\mathrm{kg} / \mathrm{m}^{3}\right)$ & 1660 & 660 & 1786 & 1450 \\
\hline Specific gravity & 2.74 & 1.33 & 2.76 & 2.18 \\
\hline Porosity (\%) & 1.52 & 5.86 & 25.00 & 11.39 \\
\hline $\begin{array}{l}\text { 24-hr. Water absorption } \\
(\%)\end{array}$ & 2.04 & 5.0 & - & - \\
\hline $\begin{array}{l}\text { Aggregate crushing value } \\
(\%)\end{array}$ & 14.65 & 3.12 & - & - \\
\hline $\begin{array}{l}\text { Aggregate abrasion value } \\
(\%)\end{array}$ & 0.85 & 1.97 & - & - \\
\hline $\begin{array}{l}\text { Aggregate impact value } \\
(\%)\end{array}$ & 0.98 & 0.61 & - & - \\
\hline Coefficient of Curvature & 1.10 & 1.17 & 0.79 & 0.68 \\
\hline Coefficient of Uniformity & 3.05 & 2.33 & 4.13 & 9.00 \\
\hline
\end{tabular}

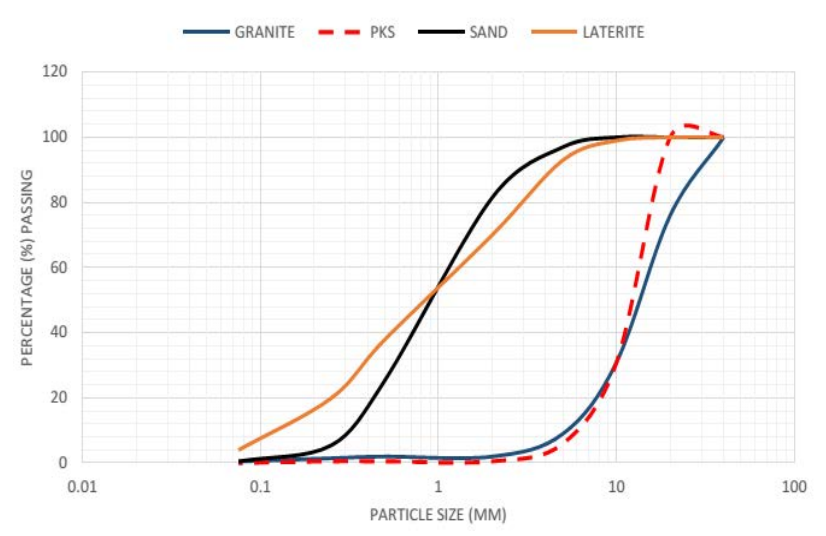

Figure 2. Particle size distribution of the aggregate, $P K S$ and laterite

Though a relatively wide range of grading for both fine and coarse aggregates is permitted by many specifications [28], some properties need to be 
mentioned. For example, from Table 2, the computed values of coefficient of uniformity $\left(C_{u}=\right.$ $\left.\frac{D_{60}}{D_{1 \mathrm{n}}}\right)$ and coefficient of curvature or gradation $\left(C_{c}=\right.$ $\left.\frac{D_{\mathrm{go}} x D_{\mathrm{go}}}{D_{\mathrm{kn}} D_{1 \mathrm{n}}}\right)$, obtained from the results of sieve analysis were 3.05 and 1.10 for the coarse aggregates, 2.33 and 1.17 for PKS, 4.13 and 0.79 for fine aggregate and 9.00 and 0.68 for laterite. Well graded aggregates that will ensure adequate compaction are considered to be the ones whose $C_{c}$ is between 1 and 3 , and $C_{\mathrm{u}}$ is greater than 4 , for coarse aggregates; and for sand, $C_{c}$ between 1 and 3 , and a $C_{u}$ greater than 6 [29]. Also, the fineness modulus of the sand of 2.78 satisfies [30] specifications for fine aggregates which require fineness modulus not to be less than 2.3 or more than 3.1. Without prejudice to the fact that the $C_{c}$ of fine aggregate and laterite which is outside of 1 and 3 , the materials (coarse aggregate, fine aggregate, laterite, palm kernel shell) as whole are suitable for the production of good concrete. It is the conclusion of [31] that "there is no one ideal grading curve but a compromise is required. Apart from the physical requirements, the economic aspects must not be forgotten: concrete has to be made of materials which can be produced cheaply so that no narrow limits can be imposed on aggregate.”

\subsection{Main investigations}

\subsubsection{Workability}

The workability characteristics of a lateritic concrete containing PKS as partial replacement of coarse aggregate are presented in Table 3.

Table 3. Workability characteristics of lateritic concrete with PKS

\begin{tabular}{|l|l|l|l|}
\hline $\begin{array}{l}\text { \% PKS } \\
\text { in Mix }\end{array}$ & $\begin{array}{l}\text { Slump } \\
(\mathrm{mm})\end{array}$ & Type & $\begin{array}{l}\text { Degree of } \\
\text { Workability }\end{array}$ \\
\hline Normal & 10 & True & Very low \\
\hline 0 & 5 & True & Very low \\
\hline 10 & 5 & True & Very low \\
\hline 20 & 0 & True & Very low \\
\hline 30 & 0 & True & Very low \\
\hline 40 & 0 & True & Very low \\
\hline 50 & 0 & Shear & Very low \\
\hline
\end{tabular}

It can be observed in Table 3 that workability, indicated by the slump values, decreased with increased addition of PKS in the mix. The specimens also displayed true slump up to $50 \%$ replacement when it was shear slump, which indicated lack of cohesion in the mix [31]. The loss of workability with increase in PKS content can be explained from the fact of the properties presented in Table 2. The values for both porosity and water absorption obtained for PKS (5.86\% and 5.0\%) are much higher than the coarse aggregate $(1.52 \%$ and $2.04 \%)$ that it replaced. This means that most of the mixing waters are trapped in the PKS, and thus not available to perform it intended functions of ensuring adequate mixing. Also, according to [31], all the concrete samples, bearing in mind their slump values, are classified as concrete with very low workability.

\subsubsection{Density}

The pattern of density development of lateritic concrete specimens with PKS as partial replacement of coarse aggregate, up to $50 \%$ replacement, is shown in Fig. 3.

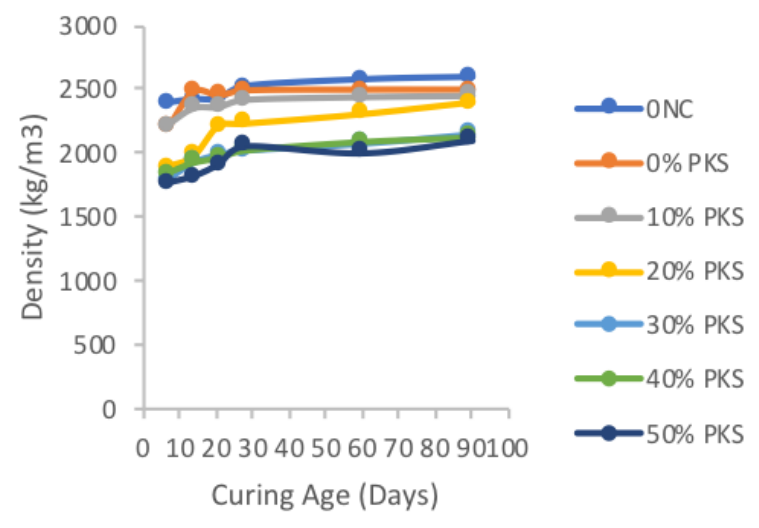

Figure 3. Density characteristics of lateritic concrete with PKS

At a given curing age, density of specimens decreased with increase in the percent replacement of coarse aggregate with PKS. For example, at 14day curing age, the densities were: 2479.21, 2351.28, 1975.31, 1925.85, 1924.92, and 1819.10 $\mathrm{kg} / \mathrm{m}^{3}$ respectively at $0,10,20,30,40$, and $50 \%$ replacement levels. This is to be expected from Table 2, where it could be observed that all the weight-based parameters (density and specific gravity) for PKS were lower than that of coarse aggregate. Numerical knowledge of density of concrete is very important if it is to be applied efficiently against the background. There exist three classes of concrete on the basis of weight namely, lightweight concrete, normal weight concrete and heavy weight concrete with densities $300-1,920$ 
$\mathrm{kg} / \mathrm{m}^{3}$, of $2,240-2,480 \mathrm{~kg} / \mathrm{m}^{3}$, and greater than $2,500 \mathrm{~kg} / \mathrm{m}^{3}$ respectively [32]. In this investigation, the 28-day numerical values of the densities of the specimens are: 2489.29, 2418.75, 2227.26, 2021.67, 2025.70 , and $2055.93 \mathrm{~kg} / \mathrm{m}^{3}$ respectively $0,10,20$, 30,40 , and $50 \%$ replacement of coarse aggregate with PKS. These densities fell within the range of $2240-2480 \mathrm{~kg} / \mathrm{m}^{3}$. It can be concluded that lateritic concrete with PKS as partial replacement of coarse aggregate of up to $50 \%$ can be used as conventional normal concrete application.

\subsubsection{Compressive strength}

The pattern of compressive strength development of lateritic concrete containing PKS as partial replacement of coarse aggregate is shown in Fig 4. First, the 28-day compressive strength of lateritic concrete at $21.17 \mathrm{~N} / \mathrm{mm}^{2}$ compares well with the compressive strength of specimens with laterite (Normal Concrete) at $23.02 \mathrm{~N} / \mathrm{mm}^{2}$ (about 8\% difference). This validated earlier results that concrete containing laterite as a partial replacement of fine aggregate up to $40 \%$ developed strength comparable with the control [4-8]. From Fig. 4, it can be observed that compressive strength increased with the curing age. This can be attributed to the formation of strength-forming C-S-H product of hydration, which is time-dependent.

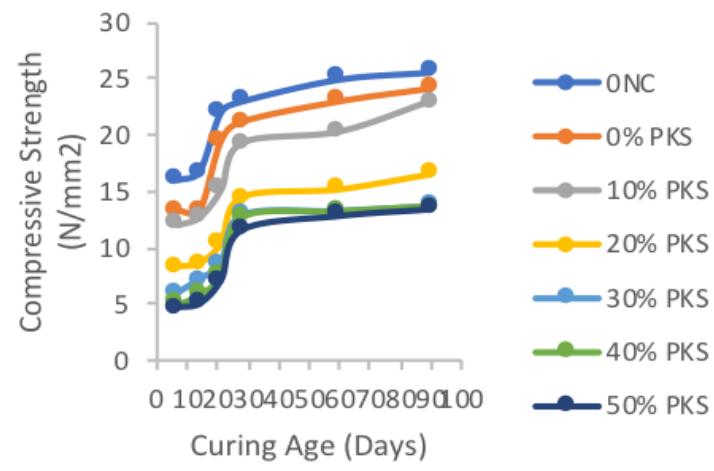

Figure 4. Compressive strength development of lateritic concrete with PKS

However, compressive strength of the specimens decreased with an increase in the content of PKS in the mix as partial replacement of coarse aggregate. The decrease was sharp as from $20 \%$ replacement upward. The 28-day compressive strengths at 0,10 , 20, 30, 40 and 50\% replacement levels are respectively 21.17, 19.27, 14.48, 12.98, 12.66 and $11.67 \mathrm{~N} / \mathrm{mm}^{2}$. This represent the difference, in relation to the control, of $8.98 \%, 31.60 \%, 38.67 \%$,
$40.20 \%$ and $44.88 \%$ respectively for $10,20,30,40$ and 50\% PKS replacement with coarse aggregate. The sharp drop in compressive strength can be due to reduced strength-forming hydration processes as the level of PKS in the mix increased, because of the absorption of the mixing water (that is needed for hydration) by the PKS due to its high porosity and high water absorption (Table 1). It is to be noticed that the compressive strength (of 19.27 $\mathrm{N} / \mathrm{mm}^{2}$ ) at $10 \%$ meets the minimum strength requirement of [33] for reinforced concrete structural elements. The standard puts the minimum 28-day cube compressive strength at $15 \mathrm{~N} / \mathrm{mm}^{2}$. The maximum value obtained in this investigation however fell short of $20 \mathrm{~N} / \mathrm{mm}^{2}$ (equivalent of 17 $\mathrm{N} / \mathrm{mm}^{2}$ cylinder strength) by $0.73 \mathrm{~N} / \mathrm{mm}^{2}$, benchmark for structural concrete set by [34, 35]. It is nonetheless practically possible to achieve this strength by using a concrete mix of low watercement ratio with superplasticizer to enhance the workability of the resulting dry mix, which will lead to higher compressive strength. It is welldocumented that low water-cement ration results in higher strength [31, 36].

\subsubsection{Microstructure and morphology of lateritic concrete with PKS}

The SEM micrographs of the lateritic concrete specimens with PKS are shown in Fig. 5 - 9. According to [37], features expected to be revealed in SEM image include: size and shape of particles, distribution of particles, particle orientations, particle concentration, and pore structure. Following the works of [37 - 39], it was assumed that the bright and dark matter in the images stand for C-S$\mathrm{H}$ gel/paste and inert aggregate respectively.

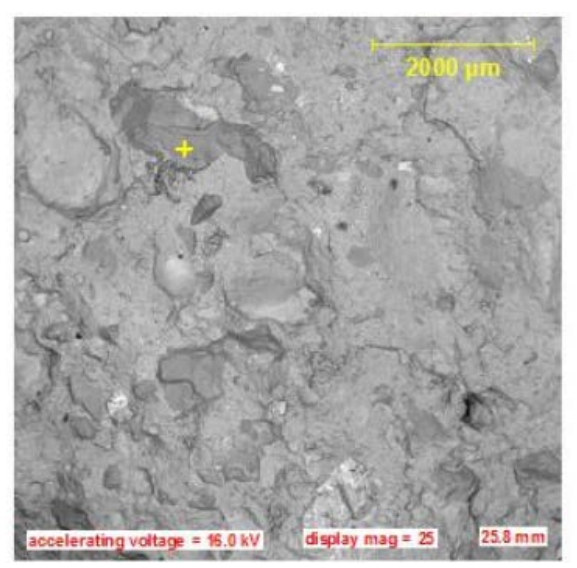

Figure 5. SEM micrograph of lateritic concrete with $0 \%$ PKS 


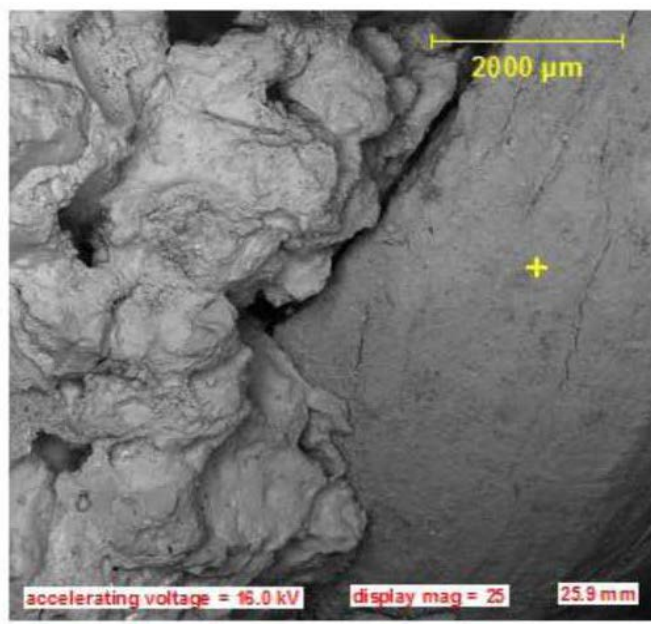

Figure 6. SEM micrograph of lateritic concrete with $10 \%$ PKS

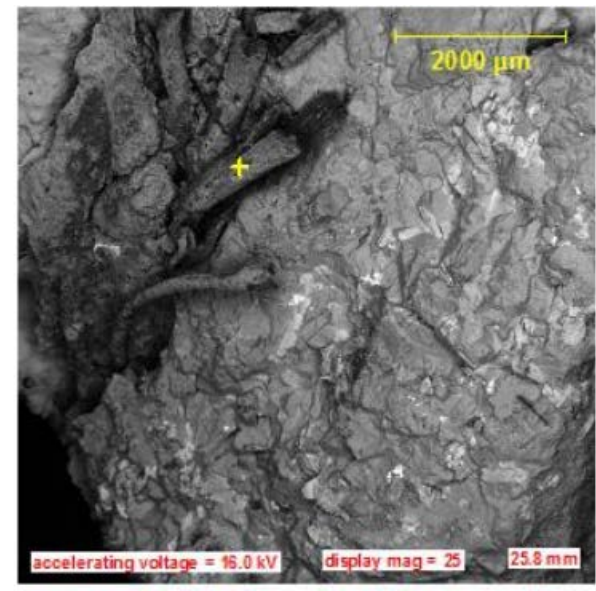

Figure 7. SEM micrograph of lateritic concrete with 20\% PKS

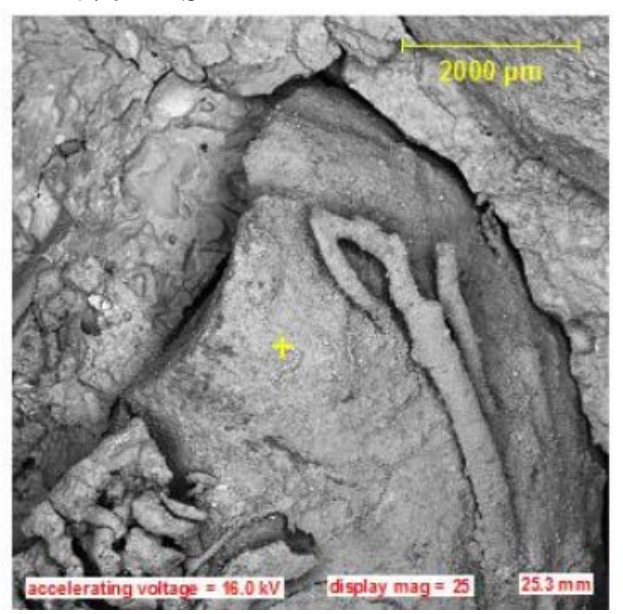

Figure 8. SEM micrograph of lateritic concrete with 40\% PKS

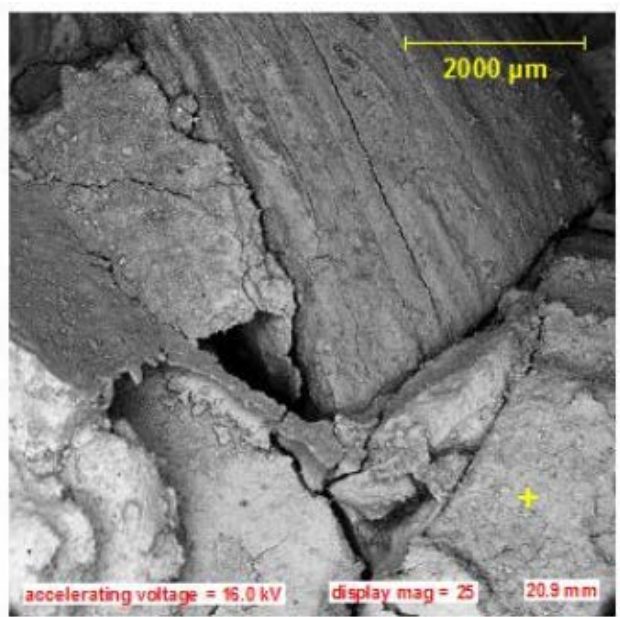

Figure 9. SEM micrograph of lateritic concrete with $50 \%$ PKS

With the knowledge about the presence of C-S-H gel/paste and inert aggregate, it can be observed that the basic structure of the concrete in all the samples is the same. Some differences in the SEM images are however obvious. While the C-S-H gel of $0 \%$ PKS sample, seems to be spread uniformly over the aggregate thereby acting as binder for the paste. The $10 \%$ PKS specimens showed a clear cleavage between the C-S-H and inert aggregate phase. Voids/pores can be seen in the hydrated cement paste. Also, poor bonding between the granite aggregate phase and the cement paste is noticed. This can be related to the poor adhesive properties of both the cement and laterite, which probably led to lower compressive strength. This trend becomes pronounced at higher PKS. For example, at 20\% PKS, fibres of PKS and sand particles can be seen in the hydrated cement paste Cracks are noticeable also around it. From the Fig. 7, it becomes evident that PKS affects the bonding between the cement paste and the aggregates by creating a bridge in between them. This affects the concrete because when the concrete is loaded, a differential movement between the aggregate and cement paste occurs which promotes the formation of cracking in the concrete sample at lower stress. Cracks result in poor strength performance of the concrete. At 40\% PKS, cracks are observed around the PKS aggregate. Cracks in concrete depend on several factors and some of them are: aggregate size and grading, cement content, water cement ratio, etc. In this investigation, the high water absorption and porosity properties of PKS aggregate reduced the water-cement ratio by absorbing some of the mixing waters. This affects the chemical reaction between 
the cement paste constituent to form calcium silicate hydrates which is responsible for the adhesion and bonding of aggregates in concrete. A much bigger cracks and voids can be seen in 50\% PKS specimen SEM image (Fig. 9). This could be a result of a crack growth at higher PKS once it has propagated, and also more voids due to progressive reduction in water-cement ratio as PKS continues to suck the mixing water. The implication of porous morphology resulting from the progressive widening of cracks and voids from the SEM images as PKS content increased in the mix is that of reduction in compressive strength with PKS [31] as the specimens failed at lower stress. Also, the volume of voids and the cracks present also affect the stiffness or the elastic modulus of the concrete. Each component (hydrated cement pastes and aggregates) may have great stiffness but the stiffness of the concrete as a whole is reduced due to the voids and cracks. This also leads to reduction in compressive strength. Figures 10 to 12 showed the EDX spectrum of typical samples.

The declining $\mathrm{Si}^{+}$count on the EDX spectrum of the samples (from 3500, 2800, and 700 at 0,10 , and $20 \%$ PKS) showed that the compound responsible for strength forming and bonding in the samples are declining, which could only result in progressively reduction in compressive strength. This gave evidence that hydration process was disturbed by paucity of water, which resulted in the presence of cracks and voids due to the porosity and high water absorption in the samples as PKS content is increased (seen in the SEM images).

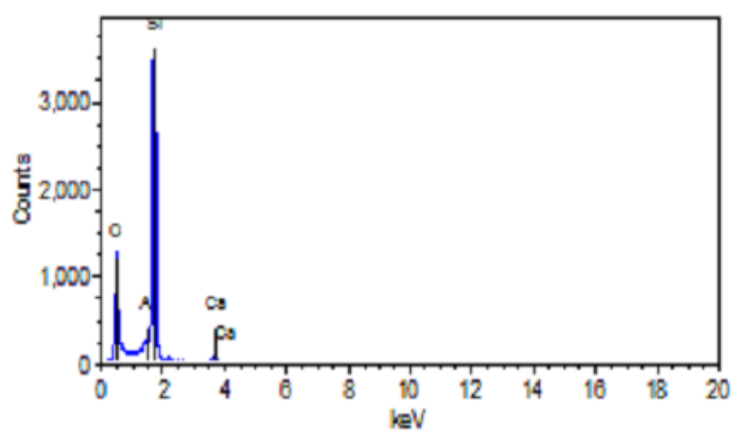

Figure 10. EDX spectrum of lateritic concrete with $0 \%$ PKS

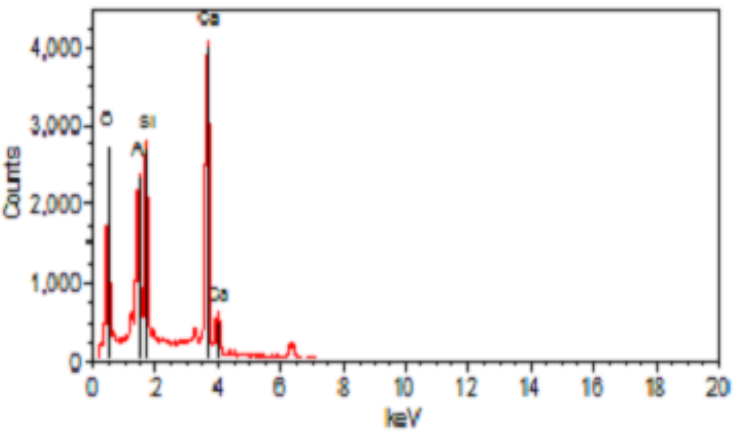

Figure 11. EDX spectrum of lateritic concrete with $10 \%$ PKS

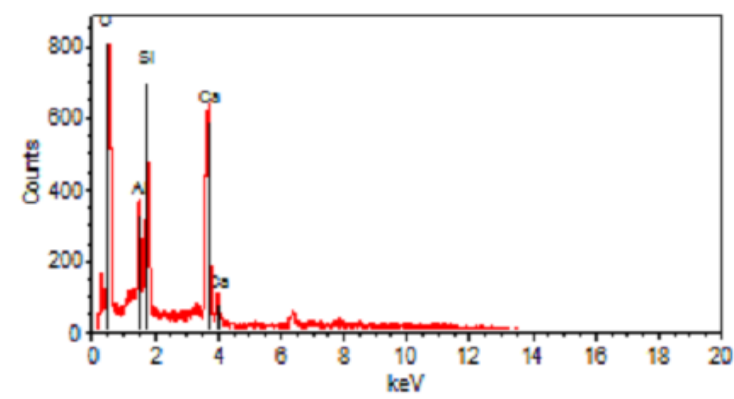

Figure 12. EDX spectrum of lateritic concrete with 20\% PKS

\subsubsection{Sorptivity and water absorption}

The results of durability performance of lateritic concrete with PKS as partial replacement of coarse aggregate, assessed through sorptivity and water absorption at 28 and 90 days are shown in Fig. 13. Both the sorptivity and water absorption of lateritic concrete samples with PKS as partial substitute of coarse aggregate showed the same pattern. The values of each increased with increase in PKS content at both 28- and 90-days curing. 


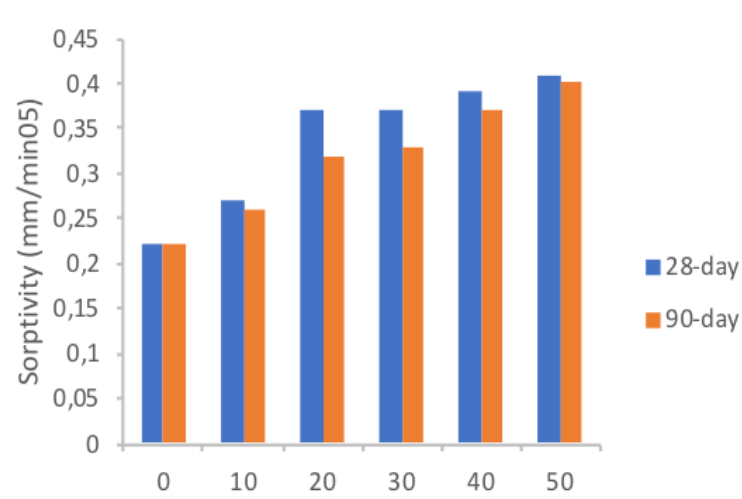

Replacement of Coarse Aggregate with PKS (\%)

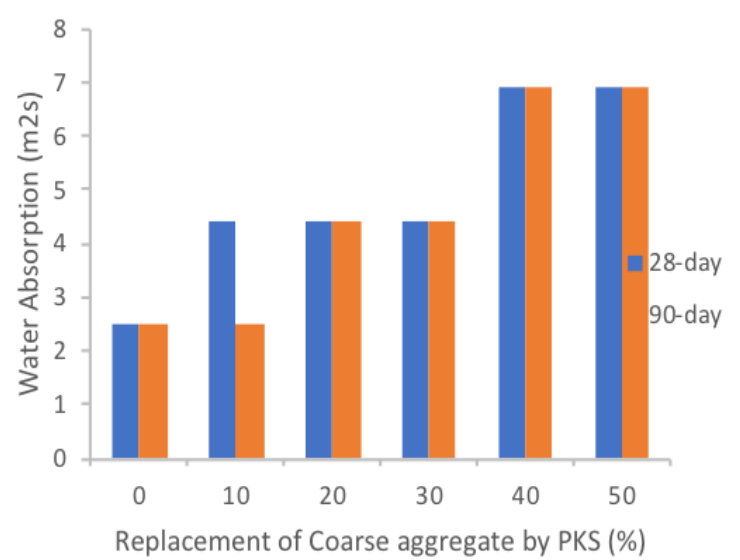

Figure 13. Sorptivity and water absorption of lateritic concrete with PKS

This increase can be attributed to increasing porosity of the specimens at higher percentages of PKS content in the mix. It has been shown in Table 2 that PKS is more porous than the coarse aggregate in addition to having higher water absorption characteristics. Its effect is to make the concrete progressively porous as it increased in quantity in the mix. Also, withdrawal of mixing water from the mix by PKS can also lead to the formation of excessive voids due to dehydration of C-S-H gel in both the mixes [40] and unhydrated compounds. This explanation agreed with [4139] who listed porosity as one of the factors that increase both the sorptivity and water absorption of concrete. The sorptivity of the specimens however reduced at 90 days. The values of the sorptivity of the specimens at 90 days were lower than the values obtained at 28 days curing. This can be explained in two ways. First, as the hydration progress with age, the products of hydration bring about a kind of pore refinement in the internal matrix of the material, with the effect that total porosity is reduced.

Secondly, the hydration products can also bring about a state of discontinuity of pores in the internal matrix, thereby making the material impervious. These reasons are also valid for the water absorption values at 90 days which are basically the same as the values obtained for 28 days. This can be seen from Fig. 13 where no changes can be observed except reduction of value at $10 \%$ replacement with PKS.

\section{Conclusions and recommendations}

This investigation was conducted to evaluate structural potential of lateritic concrete containing palm kernel shell (PKS) as partial replacement of coarse aggregates.

From the results of this investigation, the following conclusions can be made.

1) The use of PKS to partially replace the coarse aggregate in lateritic concrete resulted in harsh concrete with low workabilities.

2) Lateritic concrete with PKS as partial replacement of coarse aggregate of up to $50 \%$ developed densities that can be used for normal concrete application.

3) Lateritic concrete with PKS as partial replacement of coarse aggregate of up to $10 \%$ developed strength that is comparable to the specimens without PKS. The numerical value of the 28-day compressive strength at $10 \%$ replacement meets the requirement for usage as structural concrete as per BS 8110 (1997) and ACI (2008) international standards.

4) The morphology of lateritic samples showed a progressively porous internal structure with PKS.

5) Lateritic concrete with PKS as partial replacement of coarse aggregate result in porous material but became less porous at higher curing ages, due to discontinuity of the pores.

Innovative use of palm kernel shell and lateritic soil, where both are available, in the production of structural concrete, has been presented. Being new in the concept, paucity of literature in the area is understandable. Thus, more research is needed, covering wide range of structural issues such as 
bending response, shear behavior, tensile behavior, relationship between the compressive strength and tensile strength, etc. This is to capture the whole structural response of lateritic concrete with palm kernel shell as replacement of coarse aggregates. Usage of PKS, a waste material, in this way, can be part of a strategy in the development of an efficient waste management system. It will also help arrest the present uncontrollable usage of natural nonrenewable materials in the production of structural concrete.

\section{Acknowledgements}

The authors wish to thank the personnel in the Concrete and Materials Laboratories of the Federal University, Oye Ekiti Nigeria for their assistance during the execution of this work.

\section{References}

[1] De Blij, H. J., Miller, P. O.: Physical Geography of the Global Environment, John Wiley, New York, 1996.

[2] Ren, K. B., Kagi, D. S.: Upgrading the Durability of Mud Bricks by Impregnation, Build and Environment, 30 (1995), 440.

[3] Ata, O., Olusola, K. O., Aina, O. O.: Factors Affecting Poisson's Ratio of Laterized Concrete, Journal Sains Dan Teknologi, 15 (2005), 77-84.

[4] Falade, F. A.: Influence of Method and Duration of Curing and of Mix Proportions on Strength of Concrete Containing Laterite as Fine Aggregate, Building and Environment, 28 (1991), 4, 453-458.

[5] Osunade, J. A.: Effect of replacement of Lateritic soils with granite fines on the Compressive and Tensile Strengths of Laterized Concrete, Building and Environment, 37 (2002), 5, 491-496.

[6] Udoeyo, F. F., Udeme, H. I., Obasi, O. O.: Strength performance of laterized concrete, Construction and Building Materials, 20 (2006), 10, 1057-1062.

[7] Shuaibu, R. A., Mutuku, R. N., Nyomboi, T.: A Review of the Properties of Laterite Concrete, International Journal of Civil and Structural Engineering, 5 (2014), 130-143.

[8] Sabarish, G., Ratnam, M. K. V., Prasad, A. C., Raju, U. R.: Characteristics of Concrete with Partial Replacement of Fine Aggregate by
Laterite Sand, International Journal for Innovative Research in Science \& Technology, 2 (2015), 134-141.

[9] Alengaram, U. J., Mahmud, H., Jumaat, M. Z. Shirazi, S. M.: Effect of Aggregate Size and Proportion on Strength Properties of Palm Kernel Shell Concrete, International Journal of the Physical Sciences, 5 (2010), 12, 18481856.

[10] Alengaram, U. J., Al Muhit, B. A., Jumaat, M. Z.: Utilization of oil palm kernel shell as lightweight aggregate in concrete - A review, Construction and Building Materials, 38, (2013), 161-172.

[11] NIS 444-1, Cement - Part I: Composition and Conformity Criteria for Common Cements, Standard Organization of Nigeria, Abuja Nigeria, 2014.

[12] BS 12, Specification for Portland Cement, British Standard Institution, London, 1996.

[13] BS EN 12620:2002+A1, Specification for Aggregates from Natural Sources for Concrete, British Standards Institution, London, 2008.

[14] Adeyeri, J. B., Bolarainwa, A., Okeke, T. C.: Geotechnical Properties of Soils in Ikole-Ekiti Area, South-western Nigeria, Journal of Geotechnical Engineering (EDGE), 22 (2017), 2, $22-32$.

[15] BS EN 12350 Part 2, Method for Determination of Slump, British Standard Institution, London, 2000.

[16] BS EN 12350 Part 6, Method for Determination of Density, British Standards Institution, London, 2000.

[17] BS EN 12390-3, Testing Hardened Concrete: Compressive Strength of Test Specimens, British Standard Institution, London, 2009.

[18] Ganesan, K., Rajagopal, K., Thangavel, K.: Rice husk ash blended cement: assessment of optimal level of replacement for strength and permeability properties of concrete, Construction and Building Materials, 22 (2008), 8, 1675-1683.

[19] Giannotti da Silva, F., Liborio, J. B. L., Helene, P.: Improvement of physical and chemical properties of concrete with Brazilian silica rice husk ( $S R H)$, Revista Ingeniería de Construcción, 23 (2008), 1, 18-25.

[20] Hall, C.: Water sorptivity of mortars and concretes: A review, Magazine of Concrete Research, 41 (1989), 14, 51-61.

[21] ASTM C 1585, Standard Test Method for Measurement of Rate of Absorption of Water 
by Hydraulic Cement Concrete, American Standard for Testing Materials, Philadelphia, 2004.

[22] Stanish, K. D., Hooton, R. D., Thomas, M. D. A.: Testing the chloride penetration resistance of concrete: a literature review, FHWA contract DTFH61 1997, Department of Civil engineering, University of Toronto, Toronto, 19-22. 1997.

[23] Ukpata, J. O., Ephraim, M. E.: Flexural and Tensile Strength Properties of Concrete Using Lateritic Sand and Quarry Dust as Fine Aggregate, ARPN Journal of Engineering and Applied Sciences, 7 (2012), 324-331.

[24] Alex, A.: Shear Strength Properties of Structural Lightweight Reinforced Concrete Beams and Two-Way Slabs Using Palm Kernel Shell Coarse Aggregates, Kwame Nkrumah University of Science and Technology, 2015.

[25] BS 812, Testing Aggregates - Methods for determination of aggregate crushing value $(A C V)$, British Standards Institution, London, $1990 \mathrm{a}$

[26] BS 812, Testing Aggregates - Methods for determination of aggregate abrasion value $(A A V)$, British Standards Institution, London, 1990b.

[27] BS 812, Testing Aggregate - Methods for determination of the aggregate impact value $(A I V)$, British Standards Institution, London, 1990c.

[28] ACI-EI 99, Aggregates for Concrete, ACI Education Bulletin - E1-99, American Concrete Institute, Farmington Hills, Michigan, 1999.

[29] Terzaghi, K., Peck, R. B., Mesri, G.: Soil Mechanics in Engineering Practice, $3^{\text {rd }}$ Edition, John Wiley, New York, 1996.

[30] ASTM C33, Concrete and Aggregates-ASTM Standards, Concrete and Aggregates, American Society for Testing and Materials, Philadelphia, 1997.

[31] Neville, A. M.: Properties of Concrete, $5^{\text {th }}$ Edition, Pearson Education, London, 2011.

[32] Falade, F., Ikponmwosa, E., Arogundade, A.: Investigation of Some Structural Properties of Foamed Aerated Concrete, Journal of Engineering Research, 16 (2011), 67- 80.

[33] BS 8110, Structural use of concrete, British Standard Institution, London, 1997.

[34] ACI- 318, Building code requirements for Structural concrete (ACI 318M-08) and commentary, American Concrete Institute, Farmington Hills, Michigan, 2008.

[35] ASTM C330, Standard specification for lightweight aggregates for structural Concrete, American Society for Testing and Materials International, Philadelphia, 2009.

[36] Shetty, M. S.: Concrete Technology, Multicolor Edition, S. Chand and Company Ltd, New Delhi, 2009.

[37] Aggarwal, Y., Siddique, R.: Microstructure and Properties of Concrete using bottom ash and waste foundry sand as partial replacement of fine aggregates, Construction and Building Materials, 54 (2014), 210 - 223.

[38] Klobcar, D., Kesec, L., Pepelnjak, T., Tusek, J.: Microstructure and Mechanical Properties of Friction Stir Welded Aimg4.5Mn Alloy, Engineering Review, 32 (2012), 2, 104-110.

[39] Meng, X., Gao, S., Ma, L., Li, Z., Yue, Y., Xiao, H.: Effect of Rotational Velocity on Microstructures and Mechanical Properties of Surface Compensation Friction Stir Welded 6005A-T6 Aluminum Alloy, Engineering Review, 36 (2016), 2, 107-113.

[40] Kore, S. D., Vyas, A.K.: Impact of fire on mechanical properties of concrete containing marble waste, Journal of King Saud University - Engineering Sciences, 2017.

[41] Hall, C., Yau, M. H.: Water movement in Porous building materials. The water absorption and sorptivity of concretes, Building and Environment, 22 (1987), 1, 7782. 